\title{
Pengaruh Penerapan Hypothetico-Deductive Reasoning Dalam Learning Cycle Terhadap Keterampilan Proses Sains Dan Pemahaman Konsep Siswa
}

\author{
${ }^{1)}$ Yohn Ade Ardiyansyah, ${ }^{2)}$ Paidi \\ ${ }^{1)}$ SMK YPKK 2 Sleman, ${ }^{2}$ FMIPA Universitas Negeri Yogyakarta \\ Surat elektronik: yohnadeardiyansyah@gmail.com
}

\begin{abstract}
ABSTRAK
Penelitian ini bertujuan untuk mengetahui pengaruh penerapan hypothetico-deductive reasoning (HDR) dalam learning cycle terhadap keterampilan proses sains (KPS) dan pemahaman konsep siswa. Penelitian ini berbentuk kuasi-eksperimen dengan desain pretest-postest non-equivalent control group yaitu kelas A sebagai kelompok eksperimen bermodelkan HDR-Learning Cycle (HDR-LC), serta kelompok kontrol yaitu kelas B bermodelkan Learning Cycle (LC) dan kelas C bermodelkan Direct Instruction (DI). Sumber data KPS-intelektual dan pemahaman konsep diperoleh dengan instrumen tes sedangkan KPS-manual diperoleh dengan observasi performansi. Data dianalisis dengan MANOVA dilanjutkan uji Bonferroni, atau uji Kruskal-Wallis dilanjutkan uji Games-Howell untuk data nonparametrik. Hasil penelitian ini yaitu: (a) penerapan HDR-LC (mean: 86,4) secara signifikan berpengaruh positif terhadap KPS-intelektual dibandingkan model $L C$ (mean: 78,3) dan $D I$ (mean: 75,1). Sedangkan KPS-manual kelas HDR-LC (mean: 64,3) dibandingkan kelas $L C$ (mean: 87,4) dan DI (mean: 82,3) terdapat perbedaan yang signifikan dengan pengaruh negatif. (b) penerapan $H D R-L C$ (mean: 84,8) secara signifikan berpengaruh potisif terhadap pemahaman konsep siswadibandingkan model $L C$ (mean: 61,7) dan $D I$ (mean: 66,6). Kata kunci: hypothetico-deductive reasoning (HDR), siklus belajar, keterampilan proses sains (KPS), pemahaman konsep
\end{abstract}

\begin{abstract}
The immersion of hypothetico-deductive reasoning (HDR) application in the learning cycle for students' science process skill and concepts understanding. The reasearch aims to discover impression of hypothetico-deductive reasoning (HDR) application in the learning cycle to science process skill and concepts understanding. It's kind of quasy-experiment in type pretest-postest non-equivalent control group design in which A class were an experimental class using HDR-Learning Cycle (HDR-LC) model, B class as control class using Learning Cycle (LC) model, and C class using Direct Instruction (DI) model. The data of intellectual science process skill and concepts understanding onbtained from test whereas manual science process skill obtained from performance observation. The data had been analyzed using MANOVA continued wth Bonferroni or Kruskal-Wallis test, continued GamesHowell for nonparameteric data. The research result that: (a) application of HDR-LC (mean: 86,4) had significantly positive effect for intellectual science process skill than LC (mean: 78,3) or DI model (mean: 75,1), whereas manual science process skill HDR-LC class (mean: 64,3) had significantly negative effect than LC (mean: 87,4$)$ or DI model (mean: 82,3); (b) apllication HDR-LC (mean: 84,8) had significantly positive effect to students' understanding than LC (mean: 61,7) or DI model (mean: 66,6).
\end{abstract}

Keyword: hypothetico-deductive reasoning (HDR), learning cycle, science process skill, concepts understanding

\section{Copyright (C) 2017 Universitas Ahmad Dahlan}

\section{Pendahuluan}

Objek kajian pembelajaran biologi pada hakikatnya menyangkut dua aspek, yaitu biologi sebagai produk dan biologi sebagai proses. Biologi sebagai produk diartikan sebagai body of knowledge atau sekumpulan pengetahuan yang tersusun oleh fakta, konsep, prinsip, teori, dan hukum-hukum dalam biologi. Sedangkan biologi sebagai proses merupakan serangkaian kegiatan pembelajaran biologi yang mampu memberikan kesempatan kepada siswa untuk membangun sendiri pengetahuan konseptualnya. Depburman (2002, 154-
172) menyatakan bahwa pembelajaran biologi tidak cukup hanya dengan membekali siswa dengan pengetahuan atau konsep semata, namun siswa juga harus memposisikan dirinya layaknya seorang ilmuwan dalam menyelidiki, menginvestigasi, dan mengkonstruksi pengetahuan sains.

Berdasarkan hakikat pembelajaran biologi yang telah diuraikan di atas, pengetahuan ilmiah sebagai produk biologi harus disinergikan dengan kemampuan kerja ilmiah sehingga mampu meningkatkan literasi ilmiah (scientific literacy) siswa. Literasi ilmiah yang 
meliputi pengetahuan konseptual berbagai prinsip dan hukum dasar biologi beserta penalaran ilmiahnya dalam mengkonstruksi pengetahuan sains, pada saat ini dipertimbangkan sebagai tujuan esensial dari learning outcome untuk standar pembelajaran sains di berbagai negara (Bybee \& Fuch, 2006, 349-352; Lawson, 2009, 336-364; Turkmen \& Usta, 2007, 492).

Di Indonesia, keterampilan proses sains juga dijadikan sebagai learning outcome untuk pembelajaran biologi seperti yang dikemukakan oleh Rustaman (2005, 77-78) yang menyebutkan bahwa pembelajaran biologi menuntut adanya ketercapaian keterampilan proses sains yang ditunjukkan melalui contoh komparasi rumusan tujuan berikut: "siswa memahami ketergantungan antar makhluk hidup dengan melakukan pengamatan dan menafsirkan hasil pengamatannya" (Depdikbud, 1993, 75), dengan "siswa mampu melakukan percobaan untuk memahami saling ketergantungan di antara komponen ekosistem" (Depdikbud: 1993, 12). Rumusan pertama tujuan utamanya adalah memahami konsep, sedangkan keterampilan proses merupakan tuntutan pengalaman belajarnya, dan pada rumusan kedua tujuan utamanya adalah keterampilan proses melalui konsep tertentu.

Pengembangan keterampilan proses sains secara tegas juga dituntut untuk dimiliki oleh siswa pada kurikulum 2013 melalui pendekatan saintifik (scientific approach). Kementrian Pendidikan dan Kebudayaan (2014, 17) menyebutkan bahwa pendekatan saintifik (scientific approach) yang digunakan pada kurikulum 2013, memuat kegiatan pembelajaran yang memberikan kesempatan kepada siswa untuk melakukan kegiatan 5M yaitu: M1-mengamati (observing), M2-menanya (questioning), M3-menalar (associating), M4-mencoba (experimenting), dan M5-mengkomunikasikan (communicating). Adanya tantangan untuk membelajarkan biologi sebagai proses melalui penguatan keterampilan proses sains dengan memberikan kesempatan kepada siswa untuk mengkonstruksi sendiri pengetahuan ilmiahnya, dimungkinkan terjadinya miskonsepsi dalam memahami konsep biologi yang sedang diajarkan. Penerapan model siklus belajar berbasis penalaran ilmiah dilaporkan mampu meminimalkan kemungkinan adanya miskonsepsi dan meningkatkan keterampilan proses sains siswa. Menurut Lawson $\left(2000^{a}, 492\right)$, penerapan penalaran ilmiah secara hipotetik-deduktif dapat meningkatkan kualitas dan kemampuan generalisasi (generalizability) pada pembelajaran sains karena menuntut siswa agar melebihkan kesadaran (awareness) terhadap esensi pembelajaran yang sedang berlangsung.

Lavoie (1999, 1127-1147) melaporkan bahwa pembelajaran biologi pada tingkat menengah atas (high school) di South Dacota U.S. dengan model siklus belajar berbasis hipotetik prediksi/diskusi (hypotheticoprediction/ discussion based learning cycle) dibandingkan dengan traditional learning cycle secara signifikan meningkatkan keterampilan proses sains, kemampuan berfikir logis, konsep ilmiah, dan sikap ilmiah siswa. Taufiq \& Ketang (2009, 641-648) juga melaporkan bahwa penerapan model pembelajaran fisika dengan model siklus belajar hipotetik-deduktif (hypothetico-deductive learning cycle) di SMAN Kota Palembang pada materi keseimbangan benda tegar menunjukkan peningkatan keterampilan generik sains yang lebih tinggi secara signifikan dibandingkan dengan siswa yang memperoleh pembelajaran konvensional. Suryani et.al (2015, 111-113) juga melaporkan bahwa perangkat pembelajaran dengan model siklus belajar hipotetik-deduktif terbukti efektif untuk meningkatkan penguasaan konsep siswa pada materi larutan asam-basa.

Sesuai dengan idealisme hakikat pembelajaran biologi yang menuntut guru untuk membelajarkan "biologi sebagai proses" kepada siswa, serta berdasarkan observasi awal diketahui bahwa di SMAN 1 Sleman ditinjau dari sarana dan prasarana maupun karakter siswanya sangat potensial diterapkan model pembelajaran yang mampu memberikan penguatan pada kegiatan pembelajaran berbasis inkuiri, maka guru dihadapkan dengan permasalahan dilematis mengenai pemilihan model pembelajaran yang sesuai. Berdasarkan uraian tersebut maka perlu dilakukan analisis mengenai bukti-bukti empiris yang menunjukkan pengaruh penerapan hypothetico-deductive reasoning dalam model siklus belajar terhadap keterampilan proses sains dan pemahaman konsep siswa SMAN 1 Sleman pada konsep sistem ekskresi.

\section{Metode Penelitian}

Jenis penelitian ini adalah quasi-experimental research, dan menggunakan rancangan penelitian nonequivalent control group.

Tabel 1. Rancangan Penelitian

\begin{tabular}{crcc}
\hline Group & Pretest & $\begin{array}{c}\text { Independent } \\
\text { Variable }\end{array}$ & Postest \\
\hline $\mathrm{E}_{1}$ & $\mathrm{Y}_{11}$ & $\mathrm{X}_{\mathrm{E}}$ & $\mathrm{Y}_{21}$ \\
$\mathrm{C}_{(+)}$ & $\mathrm{Y}_{12}$ & $\mathrm{X}_{\mathrm{C}(+)}$ & $\mathrm{Y}_{22}$ \\
$\mathrm{C}_{(-)}$ & $\mathrm{Y}_{13}$ & $\mathrm{X}_{(-)}$ & $\mathrm{Y}_{33}$ \\
\hline
\end{tabular}

\begin{tabular}{|c|c|}
\hline \multicolumn{2}{|c|}{ Keterangan: } \\
\hline \multirow{5}{*}{$\mathrm{E} 1$} & kelompok eksperimen \\
\hline & kelompok kontrol positif \\
\hline & kelompok kontrol negatif \\
\hline & pembelajaran \\
\hline & $\begin{array}{l}\text { hypothetico-deductive learning cycle } \\
\text { (HDR-LC) }\end{array}$ \\
\hline 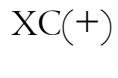 & pembelajaran dengan model \\
\hline$(-)$ & $\begin{array}{l}\text { pembelajaran dengan model } d \\
\text { instruction (DI) }\end{array}$ \\
\hline
\end{tabular}

Penelitian ini dilakukan di SMA Negeri 1 Sleman yang berlokasi di Jln. Magelang Km. 14.4 Medari, Caturharjo, Sleman, DIY pada tanggal 29 Januari hingga 29 April 2016.

Populasi penelitian ini adalah seluruh siswa jurusan MIA (Matematika dan Ilmu Alam) kelas XI SMAN 1 Sleman tahun ajaran 2015/2016 yang berjumlah 136 
siswa. Sampel penelitian ini berbentuk kelompok yaitu kelas A berjumlah 29 siswa sebagai kelas eksperimen, kelas B berjumlah 30 siswa sebagai kelas kontrol positif, serta kelas $C$ berjumlah 25 siswa sebagai kelas kontrol negatif, yang ditentukan dengan teknik purposive sampling. SMAN 1 Sleman dipilih pada penelitian didasarkan pada informasi mengenai pengalaman mengajar guru pada mata pelajaran IPA di tingkat menengah kejuruan sudah berjalan belasan tahun, namun pengalaman mengajar mata pelajaran biologi di tingkat menengah atas baru berjalan setengah semester. Adapun guru yang dimaksud pada penelitian ini, sesuai Surat Keputusan Pembagian Tugas Mengajar tahun ajaran 2015/2016 mengampu kelas A, B, dan C sedangkan kelas D dan E yang diampu oleh guru lain digunakan untuk keperluan validasi empiris instrumen penelitian.

Pengumpulan data pada penelitian ini menggunakan teknik observasi dengan instrumen berupa lembar observasi performansi untuk mengukur KPSmanual siswa, serta dengan teknik tes tertulis dengan instrumen berupa soal pretes/postes untuk mengukur KPS-intelektual dan pemahaman konsep siswa. Keterampilan proses intelektual yang melibatkan proses berpikir (minds-on) yang diukur pada penelitian ini yaitu: classifying (mengklasifikasi), predicting (menduga), hypothesizing (berhipotesis), communicating (mengkomunikasikan), interpreting data (menafsirkan), dan inferring (menyimpulkan). Sedangkan keterampilan proses manual yang melibatkan kemampuan prosedural (hands-on) pada penelitian ini yaitu: observing (mengamati), using equipment/material (menggunakan alat/bahan), measuring (mengukur), formulating models (membuat model/tabel/gambar), dan experimenting (menguji sesuai cara kerja).

Instrumen tes diberlakukan validasi isi dan konstruk dengan menyusun kisi-kisi beserta penjabaran indikatornya, sedangakan validasi muka (face validity) dilakukan melalui expert judgement oleh dua ahli materi. Validasi empiris dilakukan dengan mengujikan soal pretes/postes kepada 50 siswa kelas D dan E, dan diperoleh 20 soal pilihan ganda dan 10 soal uraian yang dinyatakan valid dan mempunyai reliabilitas tinggi yaitu sebesar 0,865 pada soal pilihan ganda dan 0,771 pada soal uraian.

Hipotesis pada penelitian ini dianalisis dengan MANOVA dan untuk mengetahui kelompok yang berbeda signifikan dilanjutkan dengan uji pos hoc Bonferroni, data yang tidak memenuhi prasyarat uji statistik parametrik maka dilakukan uji Kruskal-Wallis dan dilanjutkan uji pos hoc Games-Howell.

\section{Hasil dan Pembahasan}

\section{Hasil Pretes dan Postes Keterampilan Proses Sains} (KPS) Intelektual

Data keterampilan proses sains (KPS) intelektual siswa diperoleh dari pretes dan postes yang disajikan pada Tabel 2.
Tabel 2. Hasil Postes dan Pretes Keterampilan Proses Sains Intelektual

\begin{tabular}{lllllll}
\hline \multirow{2}{*}{ Data } & \multirow{2}{*}{ Grup } & \multirow{2}{*}{} & \multicolumn{4}{c}{ KPS-Intelektual } \\
\cline { 4 - 7 } & & & NR & NT & x & SD \\
\hline \multirow{2}{*}{ Pre- } & A & 29 & 0,0 & 56,7 & 30,8 & 13,62 \\
Tes & B & 30 & 10,0 & 70,0 & 29,3 & 16,94 \\
& C & 25 & 0,0 & 66,7 & 31,5 & 19,17 \\
Pos- & A & 29 & 50,0 & 100,0 & 86,4 & 11,09 \\
tes & B & 30 & 50,0 & 100,0 & 78,3 & 12,79 \\
& C & 25 & 60,0 & 100,0 & 75,1 & 10,81 \\
\hline
\end{tabular}

Ket: NR (nilai terendah); NT (nilai tertinggi); $x$ (rerata); dan SD (Standar Deviasi)

Berdasarkan Tabel 2 maka perbandingan nilai rerata hasil tes KPS-intelektual pada setiap kelas dapat dilihat dalam diagram pada Gambar 1.

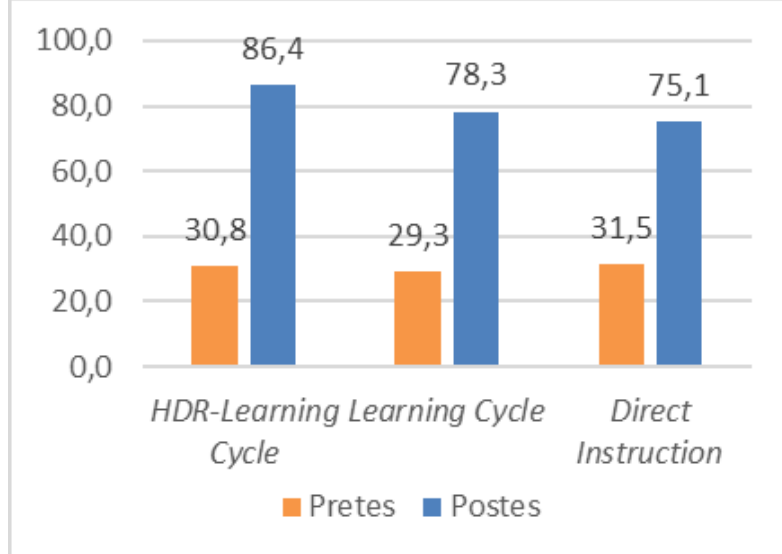

Gambar 1. Diagram Rerata Hasil Tes Keterampilan Proses Sains Intelektual

Berdasarkan Gambar 1 dapat diketahui bahwa rerata nilai awal KPS-intelektual siswa pada kelas eksperimen adalah 29,3 sedangkan pada kelas kontrol (+) dan kontrol (-) berturut-turut sebesar 29,7 dan 31,5. Setelah dilakukan pembelajaran dengan model $H D R$-learning cycle, rerata nilai KPS-intelektual siswa kelas eksperimen menjadi 86,4 sedangkan kelas kontrol $(+)$ dengan model learning cycle menjadi 78,3 dan kelas kontrol (-) dengan model direct instruction menjadi 75,1 .

Adapun nilai rerata tertinggi hasil tes KPSintelektual siswa setelah diberikan perlakuan dengan berbagai jenis model pembelajaran yang telah disebutkan adalah kelompok kelas eksperimen bermodelkan HDRLearning Cycle dengan nilai rerata postes sebesar 86.4, sedangkan nilai rerata KPS-intelektual terendah adalah pada kelmpok Direct Instruction yaitu sebesar 75,1.

Data pretes KPS-intelektual diperoleh nilai signifikansi 0,555 pada uji normalitas dan 0,069 pada uji homogenitas sehingga dapat dikatakan bahwa data tersebut berdistribusi normal dan variannya homogen, oleh karerna itu dilakukan uji beda ANOVA yang ditampilkan pada Tabel 3. 
Tabe1 3. Hasil Uji Beda ANOVA Pretes Keterampilan Proses Sains Intelektual

Pre_KPSIntel

\begin{tabular}{llllll}
\hline & $\begin{array}{c}\text { Sum of } \\
\text { Squares }\end{array}$ & df & $\begin{array}{l}\text { Mean } \\
\text { Square }\end{array}$ & F & Sig. \\
\hline $\begin{array}{l}\text { Between } \\
\text { Groups }\end{array}$ & 67.539 & 2 & 33.770 & .122 & .885 \\
Within & 22334.488 & 81 & 275.734 & & \\
Groups & & & & & \\
Total & 22402.027 & 83 & & & \\
\hline
\end{tabular}

Nilai signifikansi sebesar 0,885 pada uji ANOVA terkait nilai pretes KPS-intelektual siswa diketahui lebih dari 0,05 yang menunjukkan bahwa tidak terdapat perbedaan yang bermakna nilai pretes KPS-intelektual pada kelas yang diteliti. Hal tersebut menandakan bahwa kemampuan awal siswa pada aspek KPS-intelektual pada materi sistem ekskresi sebelum diberikan perlakuan (treatment) berupa penerapan berbagai model pembelajaran yang telah disebutkan adalah setara.

Data postes KPS-intelektual diperoleh nilai signifikansi 0,502 pada uji normalitas dan 0,634 pada uji homogenitas, sehingga dapat ditafsirkan bahwa data tersebut berdistribusi normal dan varian datanya homogen. Nilai signifikansi 0,000 pada hasil uji MANOVA ditafsirkan bahwa perlakuan yang diberikan pada penelitian ini berpengaruh terhadap aspek yang diteliti. Sedangkan nilai signifikansi 0,002 pada Test of Between-Subject Effects pada aspek KPS-intelektual menunjukkan bahwa perlakuan yang diberikan berpengaruh terhadap KPS-intelektual. Untuk mengetahui kelompok perlakuan mana yang memberikan pengaruh yang bermakna atau signifikan, maka dilanjutkan dengan uji pos hoc Bonferroni .

Tabel 4. Hasil Uji Bonferroni pada Keterampilan Proses Sains Intelektual

\begin{tabular}{lllll}
\hline $\begin{array}{llll}\text { (I) } \\
\text { Model }\end{array}$ & $\begin{array}{l}\text { (J) } \\
\text { Model }\end{array}$ & $\begin{array}{l}\text { Mean } \\
\text { Difference } \\
(\mathrm{I}-\mathrm{J})\end{array}$ & $\begin{array}{l}\text { Std. } \\
\text { Error }\end{array}$ & Sig. \\
\hline HDR-LC & LC & $8.1080^{*}$ & 3.03351 & .027 \\
& DI & $11.3814^{*}$ & 3.17912 & .002 \\
\hline LC & HDR-LC & $-8.1080^{*}$ & 3.03351 & .027 \\
& DI & 3.2733 & 3.15450 & .908 \\
\hline DI & HDR-LC & $-11.3814^{*}$ & 3.17912 & .002 \\
& LC & -3.2733 & 3.15450 & .908 \\
\hline
\end{tabular}

* The mean difference is significant at the 0.05 level.

Ket: HDR-LC : model HDR-Learning Cycle LC

: model Learning Cycle

DI

: model Direct Instruction

Berdasarkan Tabel 4 dapat diketahui bahwa KPSintelektual siswa antara kelas eksperimen bermodelkan HDR-Learning Cycle dengan kelas kontrol terdapat perbedaan yang signifikan, yaitu ditandai dengan nilai signifikansi kurang dari 0,05 yaitu sebesar 0,027 pada kelompok kontrol (+) dan sebesar 0,002 pada kelompok kontrol (-). Adapun kelompok perlakuan yang memberikan pengaruh paling baik terhadap KPSintelektual, yang ditandai dengan nilai mean difference yang positif yaitu kelompok HDR-Learning Cycle. Sedangkan KPS-intelektual siswa pada kelas kontrol $(+)$ dan kelas kontrol (-) dengan penerapan model pembelajaran berturut-turut yaitu model Learning cycle dan Direct Instruction, ternyata tidak mempunyai perbedaan yang bermakna karena nilai signifikansi lebih dari 0,05 yaitu sebesar 0,908 ,

\section{Hasil Observasi Performansi Keterampilan Proses Sains (KPS) Manual}

Data mengenai KPS-manual diperoleh berdasarkan observasi terhadap performansi siswa di dalam kegiatan praktikum uji kandungan zat dalam urin, yang ditampilkan pada Tabel 5 .

Tabel 5. Hasil Nilai Performansi Keterampilan Proses Sains Manual

\begin{tabular}{llllll}
\hline \multirow{2}{*}{ Kelas } & \multicolumn{4}{c}{ KPS-Manual } \\
\cline { 3 - 6 } & & NR & NT & $\mathbf{x}$ & SD \\
\hline A & 29 & 33,3 & 100,0 & 64,3 & 21,39 \\
B & 30 & 33,3 & 100,0 & 87,4 & 18,90 \\
C & 25 & 66,7 & 100,0 & 82,3 & 8,72 \\
\hline
\end{tabular}

Ket: NR (nilai terendah); NT (nilai tertinggi); $x$ (rerata); dan SD (Standar Deviasi)

Berdasarkan Tabel 5 maka perbandingan nilai rerata performansi KPS-manual pada setiap kelas dapat dilihat dalam diagram pada Gambar 6.

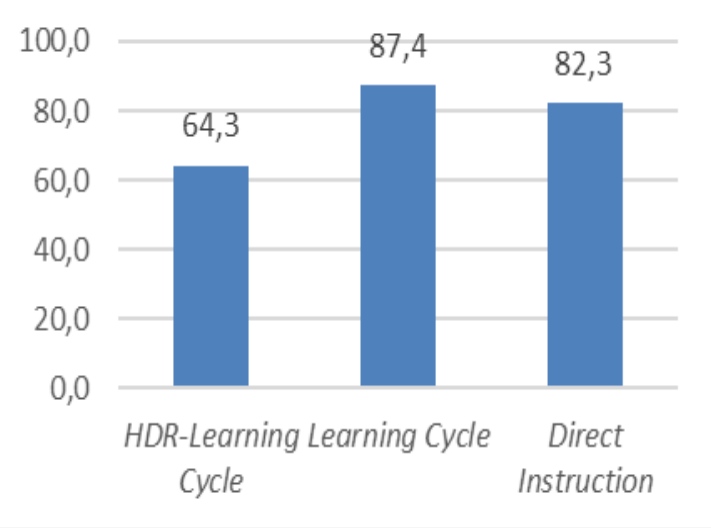

Gambar 2. Diagram Rerata Nilai Performansi Keterampilan Proses Sains Manual

Berdasarkan Gambar 2 diketahui bahwa nilai performansi KPS-manual pada kelompok HDRLearning Cycle sebagai kelompok eksperimen mempunyai rerata nilai terendah yaitu sebesar 64,3, lebih rendah dibandingkan kelompok Learning Cycle dengan nilai rerata sebesar 87,4 yang diposisikan sebagai kelompok kontrol $(+)$ dan kelompok Direct Instruction dengan nilai rerata sebesar 82,3 sebagai kelompok kontrol (-).

Data KPS-manual diperoleh nilai signifikansi kurang dari 0,05 yaitu sebesar 0,013 pada uji normalitas dan 0,002 pada uji homogenitas sehingga ditafsirkan bahwa data KPS-manual tidak berdistribusi normal dan 
varian datanya tidak homogen. Karena uji prasyarat tidak terpenuhi maka uji hipotesis pada aspek KPS-manual dilakukan dengan metode Kruskal-Wallis.

Tabel 6. Hasil Uji Kruskal-Wallis pada Keterampilan Proses Sains Manual

Kruskal-Wallis Test

Ranks

\begin{tabular}{llll}
\hline & Model_Pemb & N & $\begin{array}{l}\text { Mean } \\
\text { Rank }\end{array}$ \\
\hline KPS_ & HDR-Learning Cycle & 29 & 26.64 \\
Manu & Learning Cycle & 30 & 58.43 \\
al & Direct Instruction & 25 & 41.78 \\
& Total & 84 &
\end{tabular}

Test Statistics ${ }^{\mathrm{a}, \mathrm{b}}$

\begin{tabular}{lc}
\hline & KPS_Manual \\
\hline Chi-Square & 25.171 \\
Df & 2 \\
Asymp. Sig. & .000
\end{tabular}

Berdasarkan hasil uji Kruskal Wallis diketahui bahwa dalam hal KPS-manual siswanya, peringkat ratarata model Learning Cycle lebih tinggi dibandingkan model Direct Instruction dan model HDR-Learning Cycle dengan nilai mean rank berturut-turut 58,43; 41,78; dan 26,4. Model HDR-Learning Cycle memiliki peringkat rata-rata terendah dibandingkan kelompok kontrol penelitian. Pada uji statistik tersebut juga diketahui bahwa diperoleh nilai signifikansi 0,000 yang berarti bahwa terdapat perbedaan yang signifikan antara perlakuan (treatment) yang diberikan terhadap KPSmanual siswa. Untuk mengetahui model pembelajaran mana yang memberikan perbedaan signifikan terhadap KPS-manual siswa, maka dilanjutkan uji pos hoc Games-Howell.

Tabel 7. Hasil Uji Lanjut Games-Howell pada Keterampilan Proses Sains Manual

\begin{tabular}{lllll}
\hline Model & Model & $\begin{array}{l}\text { Mean } \\
\text { Difference } \\
\text { (I-J) }\end{array}$ & $\begin{array}{l}\text { Std. } \\
\text { Error }\end{array}$ & Sig. \\
\hline HDR-LC & LC & $-23.06253^{*}$ & 5.26154 & .000 \\
& DI & $-17.94386^{*}$ & 4.33837 & .001 \\
\hline LC & HDR-LC & $23.06253^{*}$ & 5.26154 & .000 \\
& DI & 5.11867 & 3.86662 & .390 \\
\hline DI & HDR-LC & $17.94386^{*}$ & 4.33837 & .001 \\
& LC & -5.11867 & 3.86662 & .390 \\
\hline
\end{tabular}
level.

*. The mean difference is significant at the 0.05

\begin{tabular}{|c|c|c|}
\hline Ket: & $\begin{array}{l}\text { HDR-LC } \\
\text { LC } \\
\text { DI }\end{array}$ & $\begin{array}{l}\text { : model HDR-Learning Cycle } \\
: \text { model Learning Cycle } \\
: \text { model Direct Instruction }\end{array}$ \\
\hline
\end{tabular}

Berdasarkan Tabel 7 dapat diketahui bahwa pada aspek KPS-manual, penerapan model pembelajaran yang memiliki pengaruh positif dengan perbedaan yang bermakna, yaitu yang ditandai dengan nilai signifikansi kurang dari 0,05 dan nilai Mean-Difference (I-J) yang positif, adalah penerapan model Learning Cycle dengan HDR-Learning Cycle. Selain itu KPS-manual siswa dengan penerapan model Direct Instruction juga terdapat perbedaan yang bermakna dengan pengaruh positif dibandingkan dengan model HDR-Learning Cycle. Sedangkan nilai signifikansi sebesar 0,390 antara kelas Learning Cycle dengan kelas Direct Instruction menunjukkan bahwa nilai KPS-manual siswa pada kedua kelas yang diperbandingkan tersebut tidak menunjukkan perbedaan yang bermakna.

\section{Hasil Pretes dan Postes Pemahaman Konsep}

Data pemahaman konsep siswa diperoleh dari pretes dan postes yang disajikan pada Tabel 8 .

Tabel 8. Hasil Pretes dan Postes Pemahaman Konsep

\begin{tabular}{lllllll}
\hline \multirow{2}{*}{ Data } & \multirow{2}{*}{ Grup } & \multirow{2}{*}{$\mathbf{n}$} & \multicolumn{4}{c}{ KPS-Intelektual } \\
\cline { 4 - 7 } & & & NR & NT & $\mathbf{x}$ & SD \\
\hline \multirow{2}{*}{ Pre- } & A & 29 & 15 & 65 & 36,6 & 13,70 \\
Tes & B & 30 & 10 & 40 & 29,7 & 8,30 \\
& C & 25 & 15 & 60 & 35,2 & 11.13 \\
\hline \multirow{2}{*}{ Pos- } & A & 29 & 75 & 95 & 84,8 & 12,99 \\
Tes & B & 30 & 35 & 80 & 61,7 & 11,47 \\
& C & 25 & 45 & 85 & 66,6 & 10,28 \\
\hline
\end{tabular}

Ket: NR (nilai terendah); NT (nilai tertinggi); $x$ (rerata); dan SD (Standar Deviasi)

Berdasarkan Tabel 8 maka perbandingan nilai rerata hasil tes pemahaman konsep dapat dilihat dalam diagram pada Gambar 7.

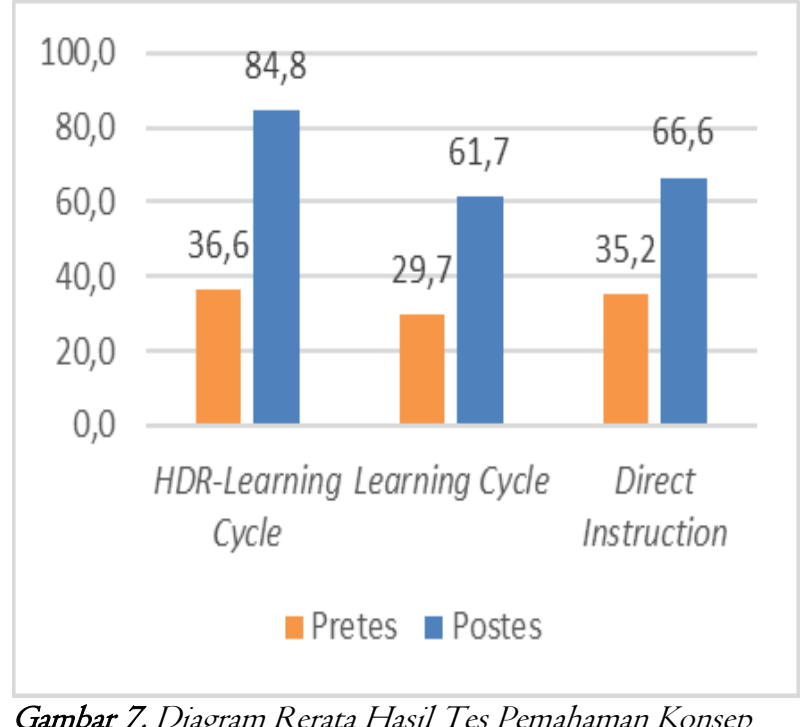

Berdasarkan Gambar 7 dapat diketahui bahwa rerata nilai awal pemahaman konsep siswa pada kelas eksperimen adalah 36,6 sedangkan pada kelas kontrol (+) dan kontrol (-) berturut-turut sebesar 29,7 dan 35,2. Setelah dilakukan pembelajaran dengan model $H D R$-learning cycle, rerata nilai pemahaman konsep siswa kelas eksperimen menjadi 84,8 sedangkan kelas kontrol (+) dengan model learning cycle menjadi 61,7 dan kelas kontrol (-) dengan model direct instruction menjadi 66,6. Adapun nilai rerata tertinggi hasil tes 
pemahaman konsep siswa setelah diberikan perlakuan dengan berbagai jenis model pembelajaran adalah kelompok kelas HDR-Learning Cycle sebesar 84,8. Sedangkan kelompok Learning Cycle mempunyai nilai rerata postes terendah yaitu sebesar 61,7 lebih rendah dibandingkan dengan kelompok Direct Instruction dengan nilai rerata postes pemahaman konsep sebesar 66,6 .

Nilai pretes pada penelitian ini dijadikan dasar sebagai pandangan bahwa kemampuan awal pada aspek pemahaman konsep sistem ekskresi dari siswa adalah setara atau relatif sama. Data pretes pada aspek pemahaman konsep diperoleh nilai signifikansi sebesar 0,101 pada uji normalitas dan 0,044 pada uji homogenitas. Hal tersebut menandakan bahwa data nilai pretes pemahaman konsep berdistibusi normal namun varian datanya tidak homogen, sehingga karena tidak memenuhi salah satu prasyarat analisis statistik parametrik maka dilakukan uji Kruskal-Wallis untuk mengetahui perbedaan antar kelompok kelas.

Tabel 9. Hasil Uji Kruskal-Wallis Nilai Pretes Pemahaman Konsep

Kruskal-Wallis Test

\begin{tabular}{ll}
\hline & Pre_PhmKnsp \\
\hline Chi-Square & 5.038 \\
Df & 2 \\
Asymp. Sig. & .081 \\
\hline
\end{tabular}

a. Kruskal Wallis Test

b. Grouping Variable: Model_Pemb

Berdasarkan Tabel 9 diketahui bahwa data pretes pemahaman konsep siswa mempunyai nilai signifikansi lebih dari 0,05 yaitu sebesar 0,081 yang mengindikasikan bahwa tidak terdapat perbedaan hasil pretes pemahaman konsep pada kelas-kelas yang diteliti. Hal tersebut dapat ditafsirkan pula bahwa kemampuan awal siswa pada pemahaman konsep sistem ekskresi sebelum diberikan perlakuan berupa berbagai jenis model pembelajaran adalah relatif sama atau setara.

Data postes pada aspek pemahaman konsep diperoleh nilai signifikansi lebih dari 0,05 yaitu sebesar 0,381 pada uji normalitas dan 0,966 pada uji homogenitas sehingga dapat ditafsirkan bahwa data nilai postes pemahaman konsep berdistribusi normal dan varian datanya bersifat homogen. Nilai signifikansi sebesar 0,000 pada hasil uji MANOVA ditafsirkan bahwa perlakuan (treatment) yang diberikan pada penelitian ini berpengaruh terhadap aspek yang diteliti. Sedangkan nilai signifikansi sebesar 0,000 pada Test of Between-Subject Effects pada aspek pemahaman konsep menunjukkan bahwa perlakuan yang diberikan pada penelitian ini berpengaruh terhadap pemahaman konsep.

Untuk mengetahui model pembelajaran atau kelompok perlakuan mana yang memberikan pengaruh yang bermakna, maka dilanjutkan dengan uji pos hoc Bonfertoni.
Tabel 10. Hasil Uji Lanjut Bonferroni pada Pemahaman Konsep

\begin{tabular}{|c|c|c|c|c|}
\hline $\begin{array}{l}\text { (I) } \\
\text { Model }\end{array}$ & $\begin{array}{l}\text { (J) } \\
\text { Model }\end{array}$ & $\begin{array}{l}\text { Mean } \\
\text { Difference } \\
(\mathrm{I}-\mathrm{J})\end{array}$ & $\begin{array}{l}\text { Std. } \\
\text { Error }\end{array}$ & Sig. \\
\hline \multirow{2}{*}{ HDR-LC } & LC & $23.1609^{*}$ & 3.04531 & .000 \\
\hline & DI & $18.2276^{\circ}$ & 3.19148 & .000 \\
\hline \multirow[t]{2}{*}{$\overline{\mathrm{LC}}$} & HDR-LC & $-23.1609^{*}$ & 3.04531 & .000 \\
\hline & DI & -4.9333 & 3.16676 & .370 \\
\hline \multirow[t]{2}{*}{$\overline{\mathrm{DI}}$} & HDR-LC & $-18.2276^{\circ}$ & 3.19148 & .000 \\
\hline & LC & 4.9333 & 3.16676 & .370 \\
\hline
\end{tabular}

* The mean difference is significant at the 0.05 level.

Ket: HDR-LC : model HDR-Learning Cycle

LC : model Learning Cycle

DI : model Direct Instruction

Berdasarkan hasil uji lanjut Bonferroni pada Tabel 10 dapat ditafsirkan bahwa pemahaman konsep siswa antara kelas eksperimen bermodelkan HDR-Learning Cycle dengan kelas kontrol (+) maupun kontrol (-) terdapat perbedaan yang signifikan, yaitu ditandai dengan nilai signifikansi kurang dari 0,05. Adapun kelompok perlakuan yang memberikan pengaruh paling baik terhadap pemahaman konsep, yang ditandai dengan nilai mean difference yang paling positif yaitu kelompok HDR-Learning Cycle. Sedangkan KPS-intelektual siswa pada kelas kontrol $(+)$ dan kelas kontrol (-) dengan penerapan model pembelajaran berturut-turut yaitu model Learning cycle dan Direct Instruction, ternyata tidak mempunyai perbedaan yang bermakna karena nilai signifikansi lebih dari 0,05 yaitu sebesar 0,370.

\section{Pembahasan}

\section{Keterampilan Proses Sains (KPS) Intelektual Siswa}

Berdasarkan hasil penelitian melalui uji ANOVA diketahui bahwa kemampuan awal siswa dari ketiga kelas yang diteliti terkait KPS-intelektualnya pada materi sistem ekskresi adalah setara atau relatif sama, sehingga dapat dipastikan bahwa terdapatnya perbedaan hasil postes KPS-intelektual pada penelitian ini benar-benar disebabkan oleh perlakuan (treatment) yang diberikan, bukan karena disebabkan oleh berbedanya ekuivalensi kemampuan awal siswanya.

Berdasarkan hasil penelitian diketahui nilai rerata pemahaman konsep siswa setelah diberikan perlakuan berupa model HDR-Learning Cycle sebesar 86,4, sedangkan pada kelompok Learning Cycle sebesar 78,3 dan 75,1 pada kelompok Direct Instruction. Hasil analisis statistik menunjukkan bahwa penerapan $H D R$ Learning Cycle memberikan pengaruh yang paling positif terhadap KPS- intelektual dibandingkan dengan penerapan model Learning Cycle maupun Direct Instruction. Hal tersebut sesuai dengan pendapat Lawson $\left(2000^{2}, 492\right)$ yang menyatakan bahwa pada hakikatnya sains berinti pada sebuah metode penelitian yang bersifat hipotetik-deduktif dengan adanya 
kesadaran (awareness) dan kekonsistenan (adherence) yang lebih tinggi maka penerapan metode tersebut dapat meningkatkan kualitas dan kemampuan generalisasi (generalizability) dalam pembelajaran sains.

Kegiatan generalisasi yang didasarkan pada gagasan hipotetik-deduktif dengan pola argumentasi jika/dan/maka merupakan inti dari metode ilmiah, sehingga dengan membelajarkan biologi secara hipotetikdeduktif maka siswa berpartisipasi aktif dalam mengkonstruksi pengetahuan konseptualnya. Kemampuan generalisasi bersinergi bersama keterampilan proses sains (KPS) intelektual yang pada penerapannya melibatkan proses berfikir (minds-on), sehingga untuk dapat melakukan generalisasi dipersyaratkan adanya pemahaman terkait konsepkonsep yang berlaku di dalamnya. Pernyataan tersebut diperkuat dengan hasil penelitian ini yang menunjukkan bahwa penerapan HDR-Learning Cycle memberikan pengaruh yang paling positif terhadap pemahaman konsep beserta KPS-intetektual siswa, dibandingkan dengan penerapan model Learning Cycle dan Direct Instruction. Hal tersebut sesuai dengan pendapat Rustaman (2005, 50) yang menyatakan bahwa pemahaman konsep merupakan hasil utama pendidikan karena konsep merupakan dasar bagi proses-proses mental yang lebih tinggi untuk merumuskan prinsipprinsip dan generalisasi-generalisasi dalam pembelajaran sains.

Berdasarkan hasil penelitian juga diketahui bahwa KPS-intelektual siswa, tidak terdapat perbedaan antara kelas Learning Cycle dan Direct Instruction. Hal tersebut dimungkinkan disebabkan oleh berbagai faktor, diantaranya ialah karena aktivitas berpikir pada KPSintelektual masih diposisikan sebagai sebuah produk sains, bukan sebagai sebuah proses sains. Dimisalkan pada kemampuan inferring (menyimpulkan) ketika disajikan tabel rancangan percobaan uji kandungan glukosa pada urin kemudian siswa diminta menarik kesimpulan berdasarkan hasil percobaan, maka siswa tidak benar-benar menyusun dan menafsirkan informasi yang diperolehnya melainkan telah diarahkan kepada kesimpulan yang benar (official definition) yang seharusnya siswa dikondisikan agar terbuka terhadap berbagai kemungkinan yang mungkin dihasilkan dari proses investigasinya.

Penerapan bernalar ilmiah secara hipotetik-deduktif (hypothetico-deductive reasoning) yang diintegrasikan ke dalam model Learning Cycle dapat dijadikan sebagai penguat (reinforcement) terhadap KPS-intelektual yang melibatkan proses berfikir (minds-on) siswa. Dengan kata lain, di dalam penalaran ilmiah yang dilakukan oleh siswa juga melibatkan kemampuan proses sains (KPS) intelektual. Hal tersebut juga ditekankan oleh Lee \& She (2010, 479-504) dan Weld et al. (2011, 101-107) yang menyatakan bahwa scientific reasoning (penalaran ilmiah) merupakan kemampuan penarikan kesimpulan dari berbagai prinsip konseptual dan bukti empiris menjadi sebuah kesimpulan baru, yang didasarkan pada kemampuan menentukan pertanyaan ilmiah, merencanakan cara menjawab pertanyaan ilmiah tesebut (eksperimen), menganalisis data, dan menginterpretasikan hasilnya.

\section{Keterampilan Proses Sains (KPS) Manual Siswa}

Kemampuan siswa terkait KPS-manual pada penelitian ini diukur berdasarkan pengamatan terhadap performansi siswa dalam kegiatan praktikum uji kandungan zat dalam urin. Berdasarkan hasil penelitian diketahui bahwa nilai rerata performansi KPS-manual siswa pada kelas HDR-Learning Cycle sebesar 64,3, lebih rendah dibandingkan kedua kelompok kontrol pada penelitian ini yaitu kelas Learning Cycle sebesar 87,4 dan kelas Direct Instruction sebesar 82,3.

Hasil analisis statistik juga menunjukkan bahwa penerapan model Learning Cycle lebih berpengaruh terhadap nilai performansi KPS-manual dibandingkan dengan model HDR-learning cycle. Hal tersebut dimungkinkan karena pada proses pembelajaran di laboratorium, satu topik kegiatan praktikum dilakukan secara bersama-sama sehingga menjadikan skor aspek yang diamati pada KPS-manual tidak maksimal pada tiap individu. Adapun pengamatan peformansi KPSmanual pada penelitian ini diuraikan menjadi lima topik dalam kegiatan praktikum antara lain; uji $\mathrm{pH}$, uji glukosa, uji protein, uji amonia, dan uji klorida.

Rendahnya nilai rerata performansi KPS-manual pada kelompok HDR-learning cycle dibanding dengan kelompok Learning Cycle juga diduga karena beberapa siswa terfokus untuk melengkapi lembar kerja siswa (LKPD) yang di dalamnya memuat perumusan masalah hingga teori yang mendasarinya sehingga menjadikannya sebagai salah satu penyebab tidak maksimalnya performansi tiap siswa. Konsekuensi dari terbatasnya waktu praktikum tersebut menjadi faktor pemicu adanya pembagian kerja kelompok yang ditandai oleh beberapa individu bertanggung jawab pada topik praktikum yang sama. Hal tersebut menjadikan beberapa individu mempunyai skor yang paling minimal pada topik praktikum yang tidak diperformansikannya.

Beberapa permasalahan yang telah diuraikan di atas terkait dengan penerapan model HDR-Learning Cycle juga dimungkinkan menjadi penyebab lebih berpengaruhnya model Direct Instruction terhadap KPS-manual siswa berdasarkan hasil analisis statistik yang telah dilakukan. Oleh karena KPS-manual pada penelitian ini bukanlah sebuah tes performansi, melainkan sebuah observasi mengenai performansi siswa dalam kegiatan praktikum uji kandungan zat dalam urin maka penerapan Direct Instruction memberikan pengaruh yang lebih signifikan terhadap KPS-manual.

Rendahnya nilai performansi KPS-manual pada kelompok HDR-learning cycle dibanding kelompok Direct Instructions juga dimungkinkan disebabkan karena model Direct Instruction memberikan atmosfir pembelajaran yang berorientasi pada tujuan (taskoriented) yaitu guru mengendalikan isi materi dan tujuan 
pembelajaran yang ingin dicapai. Oleh karena itu, pada waktu kegiatan praktikum arah pembelajaran lebih terarah dan terstruktur yaitu ditandai dengan terkonsepnya kegiatan praktikum dengan demonstrasi dan latihan terbimbing (guided practice). Searah dengan pendapat Arends (1997, 66) dan Suprihatiningrum (2013, 230) yang menyatakan bahwa model pengajaran langsung (direct instruction) dirancang untuk menunjang proses belajar siswa yang berkaitan dengan pengetahuan prosedural (procedural knowledge) dan pengetahuan deklaratif (declarative knowledge) yang terstruktur dengan baik dan diajarkan dengan pola selangkah demi selangkah.

Pengetahuan prosedural yang dibentuk melalui penerapan model Direct Instruction ditandai dengan sintaks pembelajaran berupa demonstrasi oleh guru dan latihan termbimbing. Hal tersebut berlawanan dengan HDR-Learning Cycle yang berprinsipkan adanya keterlibatan siswa dalam mengkonstruksi pengetahuannya, sedangkan pada model Direct Instruction siswa diajarkan kompetensi yang ingin dicapai dengan kegiatan yang sudah dirancang atau didesain oleh guru sehingga performansi siswa pada kelompok direct Instruction memperoleh skor yang maksimal pada tiap aspek KPS-manual. Dengan kata lain, siswa golongan bawah yang berkemampuan di bawah rata-rata kelas akan terbantu dalam memahami tujuan pembelajaran, yaitu mempraktekkan uji kandungan zat dalam urin yang menekankan pada tercapainya kemampuan prosedural siswa. Hal serupa juga disampaikan oleh Suprihatiningrum (2013, 236238) yang menyatakan bahwa model Direct Instruction efektif digunakan untuk mengajarkan keterampilanketerampilan yang eksplisit kepada siswa yang berprestasi rendah.

Berdasarkan hasil penelitian juga diketahui bahwa

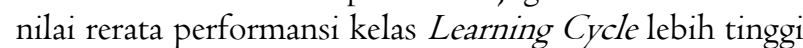
dibanding kelas Direct Instruction, yaitu sebesar 87,4 dan 82,3. Didasarkan pada hasil analisis statistik diketahui bahwa tidak terdapat perbedaan signifikan antara nilai performansi KPS-manual siswa kelas Learning Cycle dengan Direct Instruction. Hal tersebut dimungkinkan selain karena kelebihan model Direct Instruction yang telah disebutkan terkait pengembangan pengetahuan prosedural siswa, model Learning Cycle tanpa penerapan HDR memberikan efek yang serupa dengan model Direct Instruction karena siswa melakukan kegiatan praktikum sesuai dengan pembelajaran yang telah dirancang oleh guru.

\section{Pemahaman Konsep Siswa}

Berdasarkan hasil penelitian melalui uji KruskalWallis diketahui bahwa kemampuan awal siswa dari ketiga kelas yang diteliti terkait pemahaman konsepnya pada materi sistem ekskresi adalah setara atau relatif sama, yang ditandai dengan nilai sig $>0,05$ atau tidak terdapat perbedaan yang bermakna. Analisis mengenai data pretes pemahaman konsep siswa tersebut diperlukan untuk mengetahui ekuivalensi subjek-subjek penelitian yang dibagi menjadi berbagai kelompok perlakuan, sehingga dapat dipastikan bahwa terdapatnya perbedaan hasil postes pemahaman konsep adalah benarbenar disebabkan oleh perlakuan (treatment) yang diberikan pada penelitian ini.

Melibatkan subjek penelitian sebanyak 84 siswa yang dikelompokkan dalam tiga kelas, penerapan metode HDR (hypothetico-deductive reasoning) dalam model learning cycle pada penelitian ini diaktualisasikan sendiri oleh guru biologi. Diketahui bahwa nilai rerata pemahaman konsep siswa setelah diberikan perlakuan berupa model HDR-Learning Cycle sebesar 84.8, sedangkan pada kelompok Learning Cycle sebesar 61,7 dan 66,6 pada kelompok Direct Instruction.

Berdasarkan hasil analisis statisktik diketahui bahwa penerapan model HDR-learning cycle sebagai kelompok eksperimen dengan model learning cycle sebagai kelompok kontrol postitif dan direct instruction sebagai dan kontrol negatif, berpengaruh terhadap pemahaman konsep siswa. Adapun kelompok perlakuan yang teridentifikasi terdapat perbedaan yang bermakna mengenai pemahaman konsep siswa adalah penerapan model HDR-Learning Cycle dibandingkan dengan Learning Cycle dan Direct Instruction. Hal tersebut membuktikan bahwa penerapan HDR-Learning Cycle memberikan pengaruh yang lebih baik terhadap pemahaman konsep siswa dibandingkan dengan penerapan model Learning Cycle dan Direct Instruction. Model HDR-Learning Cycle membantu siswa memberikan penguatan dalam memahami konsep karena model tersebut menuntut siswa untuk melebihkan kesadarannya (awareness) dalam mengkonstruksi pengetahuan konseptualnya.

Rustaman (2005, 86) juga menyatakan hal yang serupa bahwa apabila siswa sekedar melaksanakan kegiatan pembelajaran tanpa menyadari apa yang sedang dikerjakannya, maka perolehannya kurang bermakna dan memerlukan waktu lama untuk menguasainya. Kesadaran (awareness) atau penalaran (scientific reasoning) tentang apa yang sedang dilakukanya, serta keinginan untuk melakukannya dengan tujuan untuk menguasainya adalah hal yang sangat penting. Pernyataan tersebut juga diperkuat dengan pendapat Zohar (1996, 205-219) yang melaporkan bahwa individu yang teridentifikasi mempunyai penalaran ilmiah (scientific reasoning) yang tinggi menunjukkan pemahaman konsep yang lebih tinggi. Dengan kata lain, kemampuan penalaran ilmiah yang kuat mampu membantu siswa dalam membuat koneksi di antara konsep-konsep.

Tingginya nilai rerata pemahaman konsep pada kelompok HDR-Learning Cycle dibandingkan dengan kelompok Direct Instruction yaitu sebesar 84,8 berbanding 66,6 membuktikan pula bahwa model HDR-learning cycle mampu mengatasi miskonsepsi oleh siswa yang dimungkinkan terjadi ketika terbentuk anggapan bahwa topik yang dipelajari telah disiapkan oleh guru. Pada model Direct Instruction konsep yang 
dipelajari ditransfer secara langsung kepada siswa sehingga guru menjadi pusatnya (teacher-centered) maka tidak mengherankan jika timbul anggapan dari siswa bahwa tidak perlu berfikir mendalam mengenai topik yang dipelajari karena akan disampaikan oleh guru. Konsekuensi yang ditimbulkan dari anggapan tersebut ialah siswa cenderung tidak melebihkan kesadarannya (awareness) terhadap esensi pembelajaran yang berlangsung, karena siswa tidak dilibatkan dalam mengkonstruksi pengetahuan konseptualnya. Hal tersebut sesuai dengan pendapat Suprihatiningrum (2013, 236-238) yang menyatakan bahwa diantara kelemahan model Direct Instruction ialah berkurangnya tanggung jawab siswa mengenai materi yang harus dipelajari, karena menganggap materi akan diajarkan oleh guru. Oleh karena siswa tidak dilibatkan dalam mengkonstruksi pengetahuan konseptualnya, guru sulit mendapatkan umpan balik mengenai pemahaman siswa sehingga berakibat pada kesalahpahaman siswa.

Bertolak dari kelemahan model Direct Instruction yang telah diuraikan, berdasarkan hasil penelitian diketahui bahwa pemahaman konsep siswa tidak terdapat perbedaan yang signifikan antara kelas bermodelkan Direct Instuction dengan Learning Cycle. Hal tersebut bertolak belakang dengan pendapat yang disampaikan oleh Klahr \& Nigam (2004,1-3) yang menyatakan bahwa sebuah pernyataan yang diakui dan diterima secara luas dalam pembelajaran sains dan matematika yaitu gagasan kontruktivis pembelajaran discovery (penemuan), yang merupakan kebalikan dari pembelajaran langsung (direct instruction), adalah cara terbaik untuk mendapatkan pemahaman yang mendalam mengenai fenomena sains dan prosedur tertentu. Hal tersebut dimungkinkan disebabkan oleh berbagai faktor, diantaranya ialah karena penerapan Learning Cycle mengharuskan siswa mengkonstruksi sendiri pengetahuan konseptualnya, sehingga performansi guru dalam memberikan penguatan dan pembimbingan selama pembelajaran menjadi sangat penting agar tidak terjadi miskonsepsi. Hal tersebut menguatkan gagasan bahwa penerapan metode HDR yang diintegrasikan ke dalam model Learning Cyle mampu menimalkan adanya miskonsepsi. Sesuai dengan pernyataan Rustaman (2005, 86) dan Zohar (1996, 205-219) mengenai arti penting kesadaran (awareness) melalui pengembangan bernalar ilmiah adalah penting untuk membangun pengetahuan konseptual pada pembelajaran yang bersifat konstruktivisme seperti pada model pembelajaran Learning Cycle.

Tidak berbedanya pemahaman konsep siswa kelas Learning Cycle dan Direct Instruction juga diduga berkaitan dengan karakter siswa di kelas tersebut terhadap model pembelajaran yang diterapkan. Siswa yang terbiasa memperoleh informasi secara instan dari guru, dimungkinkan kesulitan dengan pengkondisian model Learning Cycle yang menuntut siswanya menyusun dan menafsirkan informasi sesuai gagasan konstruktivisme. Hal tersebut sesuai dengan pendapat
Suprihatiningrum (2013, 236-238) yang menyatakan bahwa penekanan pada aktivitas mendengar dengan metode ceramah dalam model Direct Instruction, dan aktivitas mengamati dengan metode demonstrasi cocok bagi siswa dengan gaya belajar tersebut.

\section{Simpulan}

Pertama, penerapan bernalar ilmiah secara hipotetik-deduktif (hypothetico-deductive reasoning) dalam model siklus belajar secara signifikan berpengaruh positif terhadap keterampilan proses sains (KPS) intelektual yang melibatkan proses berfikir (minds-on) siswa karena mengharuskan siswa melebihkan kesadarannya (awareness) terhadap esensi pembelajaran yang sedang berlangsung, dan berpengaruh negatif terhadap performansi KPS-manual yang melibatkan kemampuan prosedural (hands-on) siswa kelas XI jurusan MIA di SMAN 1 Sleman tahun ajaran 2015/2016 pada materi sistem ekskresi. Kedua, penerapan bernalar ilmiah secara hipotetik-deduktif (hypothetico-deductive reasoning) dalam model siklus belajar secara signifikan berpengaruh positif terhadap pemahaman konsep siswa kelas XI jurusan MIA di SMAN 1 Sleman tahun ajaran 2015/2016 pada materi sistem ekskresi. Penerapan model siklus belajar hipotetik-deduktif menciptakan atmosfer pembelajaran yang bermakna (meaningful learning) sehingga memberikan penguatan terhadap konsep yang sedang diajarkan.

\section{Daftar Pustaka}

Arends, R.I. (1997). Classroom instruction and management. Toronto: McGraw-Hill.

Bybee, R. W., \& Fuchs, B. (2006). Preparing the 21st century workforce: a new reform in science and technology education. Journal of Research in Science Teaching, (43), 349-352.

Depburman, S. K. (2002). Learning how scientists work: experiential research projects to promote cell biology learning and scientific process skills. Journal of Research in Science Teaching, 1(4): 154-172.

Kementrian Pendidikan dan Kebudayaan. (2014). Konsep dan implementasi kurikulum 2013. Jakarta: Kemdikbud.

Klahr, D. \& M. Nigam. (2004). The equivalence of learning paths in early science instruction: effects of direct instruction and discovery learning. Psychological Science, 2004: 1-11.

Lavoie, Derrick R. (1999). Effects of emphasizing hypothetico-predictive reasoning within the science learning cycle on high school student's process skill and conceptual understandings in biology. Journal of Research in Science Teaching, 36 (10), 1127-1147.

Lawson, A.E. (2000a). A learning cycle approach to teach osmosis. The American Biology Teacher, 62 (3), 189-196. 
Lawson, A.E. (2009). basic inferences of scientific reasoning, argumentation, and discovery. Science Education, 336-364.

Lee, C.Q., \& She H.C. 2010. Facilitating students' conceptual change and scientific reasoning involving the unit of combustion. Research Science Education, (40), 479-504.

Rustaman, N.Y. (2005). Strategi belajar mengajar biologi, cetakan 1. Malang: UM Press.

Suprihatiningrum, J. (2013). Strategi pembelajaran: teori dan aplikasi. Yogyakarta: Ar-Ruzz Media.

Suryani, W., Suyatno, \& Erman. (2015). Penerapan model pembelajaran siklus belajar hipotetik-deduktif pada materi larutan asam-basa untuk meningkatkan penguasaan konsep siswa. Prosiding Seminar Nasional Kimia Universitas Negeri Surabaya, 109114.

Taufiq \& Ketang W. (2009). The application of hypothetical deductive learning cycle learning model to improve senior high school students' science generic skills on rigid body equilibrium. Proceeding of 3rd International Seminar on Science Education: Challenging Science Education in The Digital Era, 641-648

Turkmen, H. \& E. Usta. (2007). The role of learning cycle approach overcoming misconceptions in science. Kastamonu Education Journal, 15 (2), 491 500.

Weld, J., Stier M., \& Birren J. M. (2011). The development of a novel measure of scientific reasoning growth among college freshmen: the constructive inquiry science reasoning skills test. Research and Teaching, 40 (4), 101-107.

Zohar, A. (1996). Transfer and retention of reasoning strategies taught in biological contexts. Research in Science \& Technological Education, 14 (2), 205219. 